\title{
Workforce Characteristics, Workplace and Job Satisfaction, Stress, Burnout, and Happiness of Music Therapists in the United States
}

\author{
Anthony Meadows ${ }^{1}{ }^{*}$, Lillian Eyre ${ }^{2}$, Audra Gollenberg ${ }^{1}$ \\ 1 Shenandoah University, Winchester, USA \\ 2 Temple University, Philadelphia, USA \\ *ameadows2@su.edu
}

Received: 6 June 2021 Accepted: 17 January 2022 Published: 1 March 2022

Editor: Juanita Eslava-Mejia Reviewers: Lauren DiMaio, Vern Miller

\begin{abstract}
This survey research examined the work lives of music therapists in the United States. With the inclusion of data on salary, workplace and job satisfaction, stress, burnout, and happiness, a comprehensive picture of the working lives of music therapists emerges. On the whole, music therapists appear to be generally happy with their workplace and job conditions and to experience moderate stress and low burnout. Data regarding salaries reveal a complex economic landscape. Although the average full-time salary of a music therapist was $\$ 51,099.69$, salaries varied widely, with newly credentialed music therapists and those with less than six years of experience reporting lower average salaries. Variations in salaries, stress, burnout, and happiness were also evident across workplaces. Implications for the profession, including advocacy efforts, support for early-career professionals, and additional support for career development, invite further discussion.
\end{abstract}

Keywords: workforce characteristics, job satisfaction, stress, burnout, happiness, professional development, music therapists

\section{Workforce Characteristics, Workplace and Job Satisfaction, Stress, Burnout, and Happiness of Music Therapists in the United States}

Derived from a comprehensive survey of music therapists in the United States (US), this article describes the workforce characteristics, workplace and job satisfaction, stress, burnout, and happiness of board-certified music therapists. In doing so, it aims to provide a comprehensive picture of the work lives of music therapists in the US, relating these dimensions to their overall health and happiness.

\section{Study Context}

The work lives of music therapists have been examined in a broad range of ways (Clements-Cortes, 2013; Eyre \& Lee, 2015; Ferrer, 2017; Gooding, 2018a, 2018b) and 
in several different countries (Chang, 2014; Oh, 2016). This has included a focus on the influence of job demands and autonomy on burnout (Kim, 2016), the relationship between work-life factors and job satisfaction (Clements-Cortes, 2013; Gooding, 2018b), and the relationship between stress and self-care practices (Moore \& Wilhelm, 2019).

In a comprehensive examination of the field, Ferrer (2017) described current workforce trends, including salary and job creation trends, diversity, professional recognition, and challenges to the profession. In particular, Ferrer reported little change in salaries between 2010 and 2016 and significantly lower salaries than those reported by comparable health professions. They also described the ongoing challenges music therapists experience in being recognized professionally. Ferrer identified five strategies for growing the profession: 1) increasing professional advocacy efforts, 2) recruiting diverse music therapists, 3) providing alternate routes to becoming a music therapist, 4) making changes to music therapy curricula to aid recruitment and retention, and 5) helping music therapists practice self-care and prevent burnout.

Gooding (2018a, 2018b, 2019) examined the work lives of music therapists in a broad range of ways. This has included work-life factors and the job satisfaction of music therapy educators (Gooding, 2018a), the occupational health and wellbeing of music therapists (Gooding, 2018b), and burnout among music therapists (Gooding, 2019). According to Gooding, while music therapists are at average risk of burnout, work environment and work demands appear to be most commonly associated with burnout, followed by salary and workload, variables that are also relevant to the working lives and job satisfaction of music therapy educators.

Burnout among music therapists has also been examined in relation to positive change and growth, collective self-esteem, occupational identity, and self-care. Chang (2014) interviewed music therapists about their burnout experiences, concluding that self-awareness was crucial to the recovery process and essential to preventing future occurrences. Kim (2012) examined Korean music therapists' job satisfaction, collective self-esteem, and burnout. Kim found that job satisfaction significantly predicted the emotional exhaustion, depersonalization, and personal achievement subscales of the Maslach Burnout Inventory. They also determined that collective self-esteem was found to have a partial mediating effect between job satisfaction and emotional exhaustion. Further, the relationship between job satisfaction and emotional exhaustion is partially explained by how positively these music therapists perceived their profession and how they think others view them.

Oh (2016) examined the effects of Korean music therapists' burnout and self-resilience on their occupational identity. Oh found that the more burnout experienced by these music therapists, the lower their occupational identity, whereas self-resilience had a positive influence on occupational identity regardless of the level of burnout. Similarly, Vega (2010) examined the relationship between personality, burnout level, and other demographic variables on the longevity of music therapists. Vega found that the personality factor anxiety predicted emotional exhaustion, while the factor dominance predicted personal accomplishment. While no personality factor significantly predicted the factor depersonalization, both social boldness and vigilance strongly contributed to this relationship. Further, Vega also found that the highest degree earned was predictive of longevity. When taken as a whole, Vega suggested that these factors may provide a profile of music therapists who are staying, and thriving, in the field.

Occupational stress and burnout have also been discussed in terms of self-care. Moore and Wilhelm (2019) examined music therapy students' perceived stress levels and self-care practices to inform future research in this area. Music therapy students reported higher perceived stress than did undergraduate students in general and higher perceived stress than previously reported for adults in the United States. Music therapy students also reported lower frequency of self-care engagement, particularly with regards to self-awareness and physical self-care practices. Further, higher levels of perceived stress were associated with less frequent participation in self-care. Trondalen (2016) has taken a broader perspective, addressing self-care practices for music therapists in terms of the interconnection between biology (e.g., physical aspects), psy- 
chological issues (e.g., mental state, existential being), and context (e.g., work setting and home/social context). Trondalen identified a range of needs and associated resources for self-care that supported the everyday "wear and tear" of music therapists, and made important distinctions between the self-care needs of music therapists in different contexts and roles, including musicians, teachers and researchers.

Finally, music therapists' employment and service delivery have been examined during the COVID-19 pandemic (Gaddy et al., 2020). Respondents reported changes in their positions, including a decrease in client contact and an increase in alternate service delivery such as teletherapy. They expressed a range of concerns about their work lives, including being a carrier of COVID-19, being isolated from loved ones, and loss of income. Overall, however, participants reported high levels of hope for the profession and moderate levels of perceived stress, suggesting that these music therapists were adapting to service delivery changes and continuing to provide services, despite the challenges of the pandemic.

While previous research provides insights into aspects of the work lives of music therapists in various countries, a comprehensive evaluation of the work lives of music therapists in the United States has yet to be undertaken-particularly research that seeks to understand the relationships between salaries, workplace and job satisfaction, and professional development opportunities, along with detailed description of music therapists' stress, burnout, and happiness. Insights into these work life factors deepens our understanding of the overall health of the profession, while also identifying areas of strength and concern that support continued growth.

\section{Method}

\section{Participants}

A total of 7,952 music therapists credentialed by the Certification Board for Music Therapists were invited to participate in the study. Participants were sent an email invitation from an email list provided by the Certification Board for Music Therapists, with a follow-up email sent 14 days later. A total of 1,452 music therapists clicked on the link, and 1,154 of those music therapists participated in the survey, a response rate of $14.51 \%$. A total of 36 invitees opted out of the survey, and 3 emails were returned. Of those music therapists who participated, 982 completed the survey in full. The complete survey template is available in Appendix B.

\section{Ethical Approval}

This study was reviewed by the Shenandoah University Ethics Review Board protocol \#752 and was deemed exempt from review.

\section{Survey Design}

The survey utilized in this study consisted of 26 questions. It included questions related to demographics and including salary data (18 questions), workplace satisfaction (1 question; 7 items), professional development (1 question; 6 items), job satisfaction (4 questions; 20 items), stress (1 question; 11 items), burnout (1 question; 16 items), and happiness (1 question; 7 items).

Participants were sent the survey on October $20^{\text {th }}, 2019$, and the survey remained open for 25 days. Respondents were permitted to advance through the survey without answering every question.

\section{Survey Construction}

The survey was constructed over a 6-month period between April and October 2019. Demographic questions were modeled on the American Music Therapy Association workforce analysis (AMTA, 2018), with adjustments to question language in response to updated language recommendations from the Centers for Disease Control (CDC, 
n.d.). Workplace and job satisfaction questions were modeled on Eyre and Lee (2015), with additional questions added in response to a review of recommended resources from van Saane et al. (2003). Questions regarding stress, burnout, and happiness were derived from Coplan et al. (2018), with additional questions added to address the specific professional experiences of music therapists (Eyre \& Lee, 2015). Upon initial construction, the survey went through five rounds of revisions and received feedback from two colleagues with knowledge of survey design.

We used the following operational definitions to define stress, burnout, job satisfaction, workplace satisfaction, and happiness:

- Stress: "Job stress can be defined as the harmful physical and emotional responses that occur when the requirements of the job do not match the capabilities, resources, or needs of the worker. Job stress can lead to poor health and even injury" (NIOSH, 2014, p.6).

- Burnout: "Job burnout is a special type of work-related stress - a state of physical or emotional exhaustion that also involves a sense of reduced accomplishment and loss of personal identity" (Mayo Clinic, n.d, paras. 1-2).

- Job Satisfaction: "Job satisfaction is defined as the extent to which an employee feels self-motivated, content and satisfied with [their] job. Job satisfaction happens when an employee feels [they have] job stability, career growth and a comfortable work life balance." (mba SKOOL, 2021, para. 1).

- Workplace Satisfaction: A constellation of factors related to the individual's work conditions. Specific to music therapy, this includes an appropriate budget, workspace, and access to needed session materials (e.g., instruments).

- Happiness: "In a fundamental sense, workplace happiness comes when: 1) we enjoy doing the tasks assigned to us, 2) we feel right about the people we are working with, 3) we are happy with the financial benefits we get from the job, 4) We have the scope of improving our existing skills, and 5) we feel respected and acknowledged at work" (Chowdhury, n.d, para. 1).

\section{Data Analysis}

Descriptive statistics (means, medians, standard deviations, and 95\% confidence intervals) were calculated for open-ended reported salary measures. Respondents who reported hourly salaries were kept separate from annual salary values for consistency. Zero salary values $(n=44)$ for those reporting full-time or part-time employment were omitted owing to implausible values. Composite scores for the domains for happiness, burnout, stress, and workplace and job satisfaction were calculated by summing the reported values for each question in the respective sections. Analysis of variance was used to compare total composite scores by the type of setting with a two-sided test for significance. All statistical analyses were completed using SAS University Edition software (version 9.2; SAS Institute Inc., Cary, NC, USA).

\section{Results}

A total of 1,154 music therapists completed part or all of the survey. Detailed information regarding the age, gender identity, and region of these participants can be found in Appendix A. In sum, participants were predominantly female (88.2\%), and their age reflected a bimodal distribution, with most between $20-29$ years (36.7\%) and 30-39 (30.3\%). All seven regions of the American Music Therapy Association were represented, with the majority from the mid-Atlantic (27.7\%) and Great Lakes (24.7\%) regions. Respondents had been working an average of 10.87 years as a music therapist (median $=6$ years) and in their current position for an average of 5.79 years (median $=3$ years). In terms of their highest level of education, the majority of participants reported completing either a bachelor's (40.45\%) or a master's degree (35.85\%). In addition, $56.83 \%$ of respondents were members of the American Music Therapy Association. 
Table 1

Average Salary of Respondents

\begin{tabular}{|c|c|c|c|c|c|c|}
\hline \multirow[t]{2}{*}{ Salary indicator } & \multirow[t]{2}{*}{$n$} & \multirow[t]{2}{*}{$M$} & \multirow[t]{2}{*}{$S D$} & \multicolumn{2}{|c|}{$95 \% \mathrm{Cl}$} & \multirow[t]{2}{*}{$M d n$} \\
\hline & & & & $L L$ & $U L$ & \\
\hline Total reported salary & 956 & $\$ 44,373.64$ & $24,728.22$ & $42,804.13$ & $45,943.14$ & $43,000.00$ \\
\hline Total full-time salary & 594 & $\$ 51,099.69$ & $19,594.66$ & $49,520.70$ & $52,678.68$ & $48,000.00$ \\
\hline Total hourly salary & 36 & $\$ 32.40$ & 19.40 & 25.80 & 38.90 & - \\
\hline
\end{tabular}

Table 2

Average Reported Salary and Years of Employment

\begin{tabular}{|l|l|l|l|l|l|}
\hline \multicolumn{1}{|c|}{ Years working as a music therapist } & \multicolumn{1}{|c|}{$n$} & Annual salary & \multicolumn{1}{|c|}{$S D$} & \multicolumn{2}{c|}{ 95\% Cl } \\
\hline & & $M$ & & UL \\
\hline$<1$ & 104 & $\$ 34,161.60$ & $15,388.13$ & $31,168.99$ & $37,154.20$ \\
\hline $2-5$ & 341 & $\$ 38,310.49$ & $14,527.77$ & $36,763.04$ & $39,857.95$ \\
\hline $6-9$ & 160 & $\$ 45,193.38$ & $17,520.40$ & $42,457.79$ & $47,928.96$ \\
\hline $10-19$ & 173 & $\$ 49,852.57$ & $33,784.96$ & $44,782.49$ & $54,922.65$ \\
\hline $20-29$ & 92 & $\$ 53,259.91$ & $32,699.62$ & $46,488.01$ & $60,031.81$ \\
\hline $30-39$ & 63 & $\$ 54,555.35$ & $26,752.94$ & $47,817.71$ & $61,292.99$ \\
\hline $40+$ & 23 & $\$ 70,094.78$ & $44,371.77$ & $50,906.99$ & $89,282.57$ \\
\hline
\end{tabular}

Table 3

Average Reported Salary and Degree

\begin{tabular}{|c|c|c|c|c|c|}
\hline \multirow[t]{2}{*}{ Degree } & \multirow[t]{2}{*}{$n$} & \multirow{2}{*}{$\begin{array}{c}\text { Annual salary } \\
\text { M }\end{array}$} & \multirow[t]{2}{*}{$S D$} & \multicolumn{2}{|c|}{$95 \% \mathrm{Cl}$} \\
\hline & & & & $L L$ & $U L$ \\
\hline Bachelor's & 437 & $\$ 39,909.85$ & $18,875.60$ & $38,135.19$ & $41,684.51$ \\
\hline Equivalency & 84 & $\$ 44,446.51$ & $41,712.95$ & $35,394.25$ & $53,498.78$ \\
\hline Master's & 396 & $\$ 45,946.07$ & $20,002.07$ & $43,969.98$ & 47,922.17 \\
\hline Doctorate & 37 & $\$ 80,579.51$ & $42,682.70$ & $66,348.39$ & $94,810.63$ \\
\hline
\end{tabular}

\section{Salary Data}

Tables 1 through 3 provide summary data related to participant salaries. The average reported salary ${ }^{1}$ was $\$ 44,373.64(S D=24,728.22 ; 95 \% C I=42,804.13-45,943.14)$, while the average full-time salary was $\$ 51,099.69$ ( $S D=19,594.66 ; 95 \% \mathrm{CI}=$ $49,520.70-52,678.68)$. The average reported salary of a newly credentialed music therapist was $\$ 34,161.60(S D=15,388.13$; $95 \% \mathrm{CI}=31,168.99-37,154.20)$, increasing to $\$ 70,094.78$ ( $S D=44,371.77 ; 95 \% \mathrm{CI}=50,906.99-89,282.57$ ) after 40 years of work. Concomitantly, the average reported salary of a music therapist with a bachelor's degree was $\$ 39,909.85$ ( $S D=18,875.60$; 95\% CI $=38,135.19$ $41,684.51$ ), increasing to $\$ 45,946.07$ for participants with a master's degree ( $S D=$ 20,002.07; $95 \%$ CI $=43,969.98-47,922.17)$ and $\$ 80,579.51$ with a doctorate (SD $=42,682.70 ; 95 \% \mathrm{CI}=66,348.39-94,810.63$ ). Of note are the standard deviations within each of these categories, suggesting a wide range of salaries.

Table 4 summarizes average salary data by workplace, with music therapists working in medical settings $(\$ 54,311.81)$ and those working as educators $(\$ 55,139.15)$ reporting the highest salaries, whereas those who self-identified as community music 
Table 4

Average Reported Salary by Workplace

\begin{tabular}{|l|l|l|l|l|l|}
\hline \multicolumn{1}{|c|}{ Work setting } & $n$ & Annual salary & \multicolumn{1}{|c|}{$S D$} & \multicolumn{2}{c|}{$95 \% \mathrm{Cl}$} \\
\hline & & $M$ & & \multicolumn{1}{|c|}{ UL } \\
\hline Children's facilities/schools & 125 & $\$ 44,114.08$ & $20,790.19$ & $40,433.55$ & $47,794.61$ \\
\hline Community music therapy & 39 & $\$ 31,808.64$ & $18,914.87$ & $25,677.15$ & $37,940.13$ \\
\hline Older adult/long term care communities & 64 & $\$ 40,175.86$ & $16,214.20$ & $36,125.67$ & $44,226.05$ \\
\hline Hospice & 115 & $\$ 46,529.02$ & $15,642.96$ & $43,639.32$ & $49,418.72$ \\
\hline Medical settings & 98 & $\$ 54,311.81$ & $37,808.89$ & $46,731.60$ & $61,892.01$ \\
\hline Mental health, including addictions & 128 & $\$ 46,959.84$ & $15,578.46$ & $44,235.09$ & $49,684.58$ \\
\hline Other & 144 & $\$ 48,153.83$ & $27,761.61$ & $43,580.81$ & $52,726.84$ \\
\hline Self-employed and private practice & 196 & $\$ 35,128.58$ & $24,941.93$ & $31,614.97$ & $38,642.19$ \\
\hline University/college educator & 47 & $\$ 55,139.15$ & $24,974.91$ & $47,806.24$ & $62,472.06$ \\
\hline
\end{tabular}

Table 5

Average Reported Salary and Employment Status

\begin{tabular}{|c|c|c|c|c|c|}
\hline \multirow[t]{2}{*}{ Employment status } & \multirow[t]{2}{*}{$n$} & \multirow{2}{*}{$\begin{array}{c}\text { Annual salary } \\
\text { M }\end{array}$} & \multirow[t]{2}{*}{$S D$} & \multicolumn{2}{|c|}{$95 \% \mathrm{Cl}$} \\
\hline & & & & $L L$ & $U L$ \\
\hline Contracted music therapist & 140 & $\$ 31,340.79$ & $21,229.91$ & $27,793.22$ & $34,888.35$ \\
\hline Employed full time as music therapist & 594 & $\$ 51,099.69$ & $19,594.66$ & $\$ 49,520.70$ & $52,678.68$ \\
\hline Employed part time as music therapist & 158 & $\$ 30,113.04$ & $33,155.25$ & $\$ 24,903.10$ & $35,322.98$ \\
\hline Employed but not as music therapist & 44 & $\$ 46,234.39$ & $17,819.13$ & $\$ 40,816.88$ & $51,651.90$ \\
\hline Retired & 10 & $\$ 60,190.00$ & $43,969.80$ & $28,735.90$ & $91,644.10$ \\
\hline
\end{tabular}

therapists $(\$ 31,808.64)$, self-employed/private practice $(\$ 35,128.58)$ and older adult/ long term care communities $(\$ 40,195.86)$ reporting the lowest.

Table 5 summarizes average salaries by employment status, with retirees $(\$ 60,190.00)$ and respondents working full-time as music therapists $(\$ 51,099.69)$ having the highest salaries, and contracted music therapists $(\$ 31,340.79)$ the lowest. Of note are the large number of music therapists working part-time, contractually, or not using the title of "music therapist" in their employment status (41.95\%).

When asked to respond to the following statement "My music therapy income meets my basic needs," $23.6 \%$ of respondents completely agreed, $34.2 \%$ somewhat agreed, $18.7 \%$ somewhat disagreed, and $15 \%$ completely disagreed. Further, when asked to rate their degree of satisfaction with their salary, $17.5 \%$ were completely satisfied, $36.9 \%$ somewhat satisfied, $27.7 \%$ somewhat dissatisfied, and $8.7 \%$ completely dissatisfied.

\section{Workplace Satisfaction}

Table 6 provides a summary of responses to a series of questions regarding music therapists' workplace satisfaction. In general, the majority of music therapists appear to have work conditions that support their clinical work, with $79.15 \%$ of music therapists reporting completely or somewhat agreeing with the statement "I am generally happy with my work conditions," while only $14.87 \%$ reported somewhat or completely disagreeing with this statement. When respondents were asked questions about their access to an appropriate space to conduct music therapy sessions, their access to instruments, and their ability to conduct sessions without interruptions, responses varied. A total of $63.64 \%$ of respondents reported completely or somewhat agreeing that 
Table 6

Music Therapists' Work Conditions

\begin{tabular}{|c|c|c|c|c|c|c|c|c|c|c|c|}
\hline \multirow[t]{2}{*}{ Measure } & \multicolumn{2}{|c|}{$\begin{array}{l}\text { Completely } \\
\text { agree }\end{array}$} & \multicolumn{2}{|c|}{$\begin{array}{l}\text { Somewhat } \\
\text { agree }\end{array}$} & \multicolumn{2}{|c|}{$\begin{array}{l}\text { Neither } \\
\text { agree nor } \\
\text { disagree }\end{array}$} & \multicolumn{2}{|c|}{$\begin{array}{l}\text { Somewhat } \\
\text { disagree }\end{array}$} & \multicolumn{2}{|c|}{$\begin{array}{l}\text { Completely } \\
\text { disagree }\end{array}$} & \multirow[t]{2}{*}{$\begin{array}{l}\text { Weighted } \\
\text { average }\end{array}$} \\
\hline & $n$ & $\%$ & $n$ & $\%$ & $n$ & $\%$ & $n$ & $\%$ & $n$ & $\%$ & \\
\hline I am generally happy with my work conditions. & 369 & 35.62 & 451 & 43.53 & 62 & 5.89 & 125 & 12.07 & 29 & 2.80 & 2.03 \\
\hline I have adequate funds to carry out my duties. & 347 & 33.46 & 346 & 33.37 & 129 & 12.44 & 156 & 15.04 & 59 & 5.69 & 2.26 \\
\hline I am allocated an adequate budget to carry out my duties. & 312 & 30.26 & 268 & 25.99 & 203 & 19.69 & 146 & 14.16 & 102 & 9.89 & 2.47 \\
\hline $\begin{array}{l}\text { I have a budget that allows me to incorporate technologies } \\
\text { and equipment to practice advanced skills appropriate for } \\
\text { my population. }\end{array}$ & 235 & 22.75 & 271 & 26.23 & 178 & 17.23 & 182 & 17.62 & 167 & 16.17 & 2.78 \\
\hline $\begin{array}{l}\text { I have appropriate space allocated to me for my music } \\
\text { therapy sessions. }\end{array}$ & 338 & 32.69 & 320 & 30.65 & 142 & 13.73 & 159 & 15.38 & 76 & 7.35 & 2.34 \\
\hline $\begin{array}{l}\text { I have access to the instruments I need for my music thera- } \\
\text { py sessions. }\end{array}$ & 482 & 46.62 & 313 & 30.27 & 91 & 8.80 & 108 & 10.44 & 40 & 3.87 & 1.95 \\
\hline $\begin{array}{l}\text { I can carry out most sessions with my clients without inter- } \\
\text { ruptions. }\end{array}$ & 280 & 27.11 & 345 & 33.40 & 107 & 10.36 & 201 & 19.46 & 100 & 9.68 & 2.51 \\
\hline
\end{tabular}

they were allocated an appropriate space for sessions $(23.15 \%$ somewhat or completely disagreed), $76.89 \%$ reported access to the instruments they need $(14.31 \%$ somewhat or completely disagreed), and $60.51 \%$ were able to conduct sessions without interruptions from staff members (29.14\% somewhat or completely disagreed). Similarly, $67.16 \%$ of respondents reported completely or somewhat agreeing with the statement "I have adequate funds to carry out my duties" (20.73\% somewhat or completely disagreed), $56.28 \%$ reported allocation of an adequate budget to carry out their duties (24.05\% somewhat or completely disagreed), and $48.98 \%$ of respondents reported having a budget that allowed them to incorporate technologies and equipment to practice advanced skills appropriate for their population (33.79\% somewhat or completely disagreed).

\section{Job Satisfaction}

Table 7 summarizes responses to a series of questions regarding job satisfaction. In general, the majority of music therapists appear to be satisfied with their jobs, with $67.79 \%$ of respondents somewhat or completely agreeing with the statement "I am satisfied with the ratio of group and individual work in my work week" (16.60\% somewhat or completely disagreed). Further, $62.56 \%$ reported that the number of clients in groups was appropriate for effective therapy $(17.42 \%$ somewhat or completely disagreed), and $81.05 \%$ reported they had opportunities to use the most appropriate music therapy interventions for their population $(10.47 \%$ somewhat or completely disagreed).

Regarding access to client records, their ability to assess clients, and their ability to document client progress, respondents reported the following: $73.47 \%$ of respondents reported somewhat or complete agreement with the statement "I can access client records in a timely manner so that I can assess clients appropriately" (15.78\% somewhat or completely disagreed). A total of $84.65 \%$ reported opportunities to document client progress (8.46\% somewhat or completely disagreed), $67.23 \%$ reported adequate time for documentation (22.54\% somewhat or completely disagreed), and $61.86 \%$ reported that their documentation of client sessions was valued by their employer (21.24\% somewhat or completely disagreed).

Regarding their participation in team meetings and their ability to access appropriate supervision, respondents reported the following: $65.81 \%$ of respondents somewhat 
Table 7

Music Therapists' Job Satisfaction

\begin{tabular}{|c|c|c|c|c|c|c|c|c|c|c|c|}
\hline \multirow[t]{2}{*}{ Measure } & \multicolumn{2}{|c|}{$\begin{array}{l}\text { Completely } \\
\text { agree }\end{array}$} & \multicolumn{2}{|c|}{$\begin{array}{l}\text { Somewhat } \\
\text { agree }\end{array}$} & \multicolumn{2}{|c|}{$\begin{array}{l}\text { Neither } \\
\text { agree nor } \\
\text { disagree }\end{array}$} & \multicolumn{2}{|c|}{$\begin{array}{c}\text { Somewhat } \\
\text { disagree }\end{array}$} & \multicolumn{2}{|c|}{$\begin{array}{l}\text { Completely } \\
\text { disagree }\end{array}$} & \multirow[t]{2}{*}{$\begin{array}{l}\text { Weighted } \\
\text { average }\end{array}$} \\
\hline & $n$ & $\%$ & $n$ & $\%$ & $n$ & $\%$ & $n$ & $\%$ & $n$ & $\%$ & \\
\hline $\begin{array}{l}\text { I am satisfied with the ratio of group to individual work in } \\
\text { my work week. }\end{array}$ & 404 & 40.16 & 278 & 27.63 & 157 & 15.61 & 122 & 12.13 & 45 & 4.47 & 2.13 \\
\hline $\begin{array}{l}\text { The number of clients I have in each group is appropriate } \\
\text { for the effective delivery of music therapy. }\end{array}$ & 291 & 30.19 & 312 & 32.37 & 193 & 20.02 & 127 & 13.17 & 41 & 4.25 & 2.29 \\
\hline $\begin{array}{l}\text { In my work setting I have the opportunity to use the most } \\
\text { appropriate music therapy interventions for my popula- } \\
\text { tion. }\end{array}$ & 460 & 45.41 & 361 & 35.64 & 86 & 8.49 & 88 & 8.69 & 18 & 1.78 & 1.86 \\
\hline $\begin{array}{l}\text { I can access client records in a timely manner so that I } \\
\text { can assess clients appropriately. }\end{array}$ & 541 & 53.35 & 204 & 20.12 & 109 & 10.75 & 100 & 9.89 & 60 & 5.92 & 1.95 \\
\hline I have the opportunity to document my clients' progress. & 622 & 61.22 & 238 & 23.43 & 70 & 6.89 & 56 & 5.51 & 30 & 2.95 & 1.66 \\
\hline I have adequate time in my schedule for documentation. & 395 & 38.88 & 288 & 28.35 & 104 & 10.24 & 156 & 15.35 & 73 & 7.19 & 2.24 \\
\hline $\begin{array}{l}\text { My documentation of client sessions is valued by my em- } \\
\text { ployer. }\end{array}$ & 383 & 37.85 & 243 & 24.01 & 171 & 16.90 & 133 & 13.14 & 82 & 8.10 & 2.30 \\
\hline $\begin{array}{l}\text { I am included in team meetings appropriate to my work } \\
\text { duties. }\end{array}$ & 403 & 39.82 & 263 & 25.99 & 151 & 14.92 & 115 & 11.36 & 80 & 7.91 & 2.22 \\
\hline My perspective on clients is valued in team meetings. & 360 & 35.61 & 305 & 30.17 & 200 & 19.78 & 94 & 9.30 & 52 & 5.14 & 2.18 \\
\hline $\begin{array}{l}\text { I have access to music therapy or creative arts supervi- } \\
\text { sion at my job. }\end{array}$ & 233 & 23.05 & 138 & 13.65 & 126 & 12.46 & 140 & 13.85 & 374 & 36.99 & 3.28 \\
\hline I have access to non-music therapy supervision at my job. & 312 & 30.80 & 256 & 25.27 & 129 & 12.73 & 135 & 13.33 & 181 & 17.8 & 2.62 \\
\hline
\end{tabular}

or completely agreed with the statement "I am included in team meetings appropriate to my work duties" (19.27\% somewhat or completely disagreed) and $65.78 \%$ reported that their perspectives on clients were valued in team meetings $(14.44 \%$ somewhat or completely disagreed). Further, $36.70 \%$ of respondents reported access to music therapy or creative arts therapy supervision $(50.84 \%$ somewhat or completely disagreed), while $56.07 \%$ of respondents reported access to non-music therapy supervision (31.03\% somewhat or completely disagreed).

\section{Professional Development Opportunities}

Table 8 provides a summary of responses to a series of questions regarding music therapists' professional development opportunities, with responses to questions regarding access to learning opportunities, conferences, and research varying considerably. When asked whether they had "the same number of learning opportunities (in-services, meetings, lectures, etc.) in [their] workplace that [their] colleagues do," $56.26 \%$ somewhat or completely agreed, whereas $28.77 \%$ somewhat or completely disagreed. A total of $40.43 \%$ reported financial support from their employer to attend a conference, whereas $45.54 \%$ somewhat or completely disagreed when asked if they received this type of financial support. A similar distribution of responses was evident when respondents were asked about financial support for continuing education: $41.68 \%$ somewhat or completely agreed with the statement "my employer provides financial support for continuing education," whereas $44.92 \%$ somewhat or completely disagreed.

When asked if they received paid time off to attend conferences or continuing education opportunities, $47.73 \%$ somewhat or completely agreed that their employer provided paid time off for at least one conference a year, and $40.83 \%$ responded similarly for continuing education. In contrast, $40.43 \%$ somewhat or completely disagreed that 
Table 8

Music Therapists' Professional Development Opportunities

\begin{tabular}{|c|c|c|c|c|c|c|c|c|c|c|c|}
\hline \multirow[t]{2}{*}{ Measure } & \multicolumn{2}{|c|}{$\begin{array}{l}\text { Completely } \\
\text { agree }\end{array}$} & \multicolumn{2}{|c|}{$\begin{array}{l}\text { Somewhat } \\
\text { agree }\end{array}$} & \multicolumn{2}{|c|}{$\begin{array}{l}\text { Neither } \\
\text { agree nor } \\
\text { disagree }\end{array}$} & \multicolumn{2}{|c|}{$\begin{array}{l}\text { Somewhat } \\
\text { disagree }\end{array}$} & \multicolumn{2}{|c|}{$\begin{array}{l}\text { Completely } \\
\text { disagree }\end{array}$} & \multirow[t]{2}{*}{$\begin{array}{l}\text { Weighted } \\
\text { average }\end{array}$} \\
\hline & $n$ & $\%$ & $n$ & $\%$ & $n$ & $\%$ & $n$ & $\%$ & $n$ & $\%$ & \\
\hline $\begin{array}{l}\text { Should I choose, I have opportunities for research at my } \\
\text { job and the support to do so. }\end{array}$ & 179 & 17.65 & 193 & 19.03 & 244 & 24.06 & 166 & 16.37 & 232 & 22.88 & 3.08 \\
\hline $\begin{array}{l}\text { I have the same number of learning opportunities (ser- } \\
\text { vices, meetings, lectures, etc.) in my job as my colleagues } \\
\text { do. }\end{array}$ & 348 & 34.29 & 233 & 21.97 & 152 & 14.98 & 163 & 16.06 & 129 & 12.71 & 2.51 \\
\hline $\begin{array}{l}\text { My employer provides financial support to attend at least } \\
\text { one conference a year. }\end{array}$ & 258 & 25.44 & 152 & 14.99 & 122 & 12.03 & 109 & 10.75 & 373 & 36.79 & 3.18 \\
\hline $\begin{array}{l}\text { My employer provides paid time off to attend at least one } \\
\text { conference a year. }\end{array}$ & 339 & 33.43 & 145 & 14.30 & 120 & 11.83 & 78 & 7.69 & 332 & 32.74 & 2.92 \\
\hline $\begin{array}{l}\text { My employer provides financial support for continuing } \\
\text { education. }\end{array}$ & 251 & 24.73 & 172 & 16.95 & 137 & 13.50 & 86 & 8.47 & 370 & 36.45 & 3.15 \\
\hline $\begin{array}{l}\text { My employer provides paid time off for continuing educa- } \\
\text { tion. }\end{array}$ & 259 & 25.54 & 155 & 15.29 & 150 & 14.79 & 90 & 8.88 & 361 & 35.60 & 3.14 \\
\hline
\end{tabular}

their "employer provides paid time off to attend at least one conference a year," and $44.48 \%$ responded similarly when asked about continuing education.

Finally, when asked "should I choose, I have opportunities for research at my job and the support to do so" $36.68 \%$ of respondents somewhat or completely agreed, whereas $39.25 \%$ somewhat or completely disagreed.

\section{Workplace Stress}

Table 9 provides a summary of responses to a series of questions regarding workplace stress. When asked if they felt like a "cog in the wheel" in their workplace, $36.47 \%$ of respondents indicated this was somewhat or completely untrue, whereas $38.68 \%$ indicated it was somewhat or completely true. Additionally, 53.5\% indicated the statement "I feel a lack of professional fulfillment" was either somewhat or completely untrue, whereas $36.62 \%$ indicated this was somewhat or completely true. Further, while $51.6 \%$ of respondents indicated that the statement "I feel that I am not able to provide clients with the quality of care that they need" was somewhat or completely untrue, $35.82 \%$ indicated it was somewhat or completely true.

When asked about their workloads, $27.41 \%$ of respondents indicated that "I feel that I spend too much time working" is somewhat or completely true, whereas $53.52 \%$ indicated that this was somewhat or completely untrue. Further, when asked to respond to the statement "I feel that I have too many administrative tasks," $29.34 \%$ of respondents reported this to be somewhat or completely true, whereas $53.52 \%$ indicated it was somewhat or completely untrue.

Respondents were also asked two questions about the relationship between their training and their job. When asked to respond to the question "I feel that my training has prepared me adequately to fulfill the demands of my job," $76.21 \%$ of respondents indicated this was somewhat or completely true, whereas $14.31 \%$ of respondents indicated this was somewhat or completely untrue. Further, when asked if their training was far beyond their job, $27.03 \%$ of respondents indicated this was somewhat or completely true, whereas $48.32 \%$ indicated this was somewhat or completely untrue. 
Table 9

Workplace Stress

\begin{tabular}{|c|c|c|c|c|c|c|c|c|c|c|c|}
\hline \multirow[t]{2}{*}{ Measure } & \multicolumn{2}{|c|}{$\begin{array}{c}\text { Completely } \\
\text { true }\end{array}$} & \multicolumn{2}{|c|}{$\begin{array}{c}\text { Somewhat } \\
\text { true }\end{array}$} & \multicolumn{2}{|c|}{$\begin{array}{l}\text { Neither true } \\
\text { nor untrue }\end{array}$} & \multicolumn{2}{|c|}{$\begin{array}{l}\text { Somewhat } \\
\text { untrue }\end{array}$} & \multicolumn{2}{|c|}{$\begin{array}{c}\text { Completely } \\
\text { untrue }\end{array}$} & \multirow[t]{2}{*}{$\begin{array}{l}\text { Weighted } \\
\text { average }\end{array}$} \\
\hline & $n$ & $\%$ & $n$ & $\%$ & $n$ & $\%$ & $n$ & $\%$ & $n$ & $\%$ & \\
\hline I feel like I am a "cog in the wheel" in my workplace. & 87 & 8.72 & 299 & 29.96 & 248 & 24.85 & 157 & 15.73 & 207 & 20.74 & 3.10 \\
\hline I feel a lack of professional fulfillment. & 99 & 9.77 & 272 & 26.85 & 100 & 9.87 & 238 & 23.49 & 304 & 30.01 & 3.37 \\
\hline I feel that I have too many administrative tasks. & 91 & 9.02 & 205 & 20.32 & 173 & 17.15 & 271 & 26.86 & 269 & 26.66 & 3.42 \\
\hline I feel that I spend too much time working. & 147 & 14.51 & 232 & 22.90 & 169 & 16.68 & 244 & 24.09 & 221 & 21.82 & 3.16 \\
\hline $\begin{array}{l}\text { I feel that I am not able to provide clients with the } \\
\text { quality of care that they need. }\end{array}$ & 83 & 8.28 & 276 & 27.54 & 126 & 12.57 & 259 & 25.85 & 258 & 25.75 & 3.33 \\
\hline I feel that I have too many difficult patients. & 35 & 3.48 & 112 & 11.14 & 167 & 16.62 & 287 & 28.56 & 404 & 40.20 & 3.91 \\
\hline $\begin{array}{l}\text { I feel that I have too many dangerous patients (aggres- } \\
\text { sive or prone to violence towards me). }\end{array}$ & 22 & 2.18 & 78 & 7.75 & 104 & 10.33 & 190 & 18.87 & 613 & 60.87 & 4.29 \\
\hline $\begin{array}{l}\text { I feel that I have to work with difficult colleagues or } \\
\text { staff. }\end{array}$ & 67 & 6.63 & 214 & 21.17 & 160 & 15.83 & 239 & 23.64 & 331 & 32.74 & 3.55 \\
\hline I feel that I have a difficult employer. & 79 & 7.85 & 151 & 15.00 & 155 & 15.39 & 192 & 19.07 & 430 & 42.70 & 3.74 \\
\hline $\begin{array}{l}\text { I feel that my training has prepared me adequately to } \\
\text { fulfill the demands of my job. }\end{array}$ & 380 & 37.51 & 392 & 38.70 & 96 & 9.48 & 101 & 9.97 & 44 & 4.34 & 2.05 \\
\hline $\begin{array}{l}\text { I feel that my training is far beyond the requirements of } \\
\text { my job. }\end{array}$ & 124 & 12.28 & 149 & 14.75 & 249 & 24.65 & 236 & 23.37 & 252 & 24.95 & 3.34 \\
\hline
\end{tabular}

\section{Burnout}

Table 10 provides a summary of participant responses regarding burnout. In the first series of questions, participants were asked about their enthusiasm for work, their level of personal accomplishment, and their thoughts about the future. A total of $80.4 \%$ of respondents somewhat or completely agreed with the statement "I feel enthusiastic about my work," whereas only $10.6 \%$ somewhat or completely disagreed. Additionally, $31.93 \%$ of participants reported somewhat or completely agreeing with the statement "I feel cynical about my work," whereas $53.52 \%$ somewhat or completely disagreed. Further, $29.6 \%$ of respondents somewhat or completely agreed with the statement "I feel a low level of personal accomplishment," whereas 59.2\% somewhat or completely disagreed with this statement. When asked two questions about their future, $64.07 \%$ of respondents somewhat or completely agreed with the statement "I feel positive about my future career path," and $62.01 \%$ somewhat or completely agreed with the statement "I am excited about the next five years of work as a music therapist."

The next series of questions addressing burnout focused on clients/patients, colleagues, and administrators. When asked if their work is "greeted with enthusiasm by [their] clients/patients," $92.84 \%$ somewhat or completely agreed, whereas $3.02 \%$ somewhat or completely disagreed. Similarly, when asked about the extent to which their work is valued by their patients, $94.45 \%$ somewhat or completely agreed, while $1.21 \%$ somewhat or completely disagreed. When asked about the extent to which their work is understood by their colleagues, $58.84 \%$ somewhat or completely agreed, while $28.21 \%$ somewhat or completely disagreed. Further, when asked to respond to the statement "my work is valued by my colleagues," $80.99 \%$ somewhat or completely agreed, while $8.65 \%$ somewhat or completely disagreed. Finally, when asked to respond to the statement "my work is understood by my administrators," $51.96 \%$ somewhat or completely agreed, while $33.43 \%$ somewhat or completely disagreed. When asked to respond to the question "my work is valued by my administrators," $64.85 \%$ somewhat or completely agreed, while $19.8 \%$ somewhat or completely disagreed. 
Table 10

Burnout

\begin{tabular}{|c|c|c|c|c|c|c|c|c|c|c|c|}
\hline \multirow[t]{2}{*}{ Measure } & \multicolumn{2}{|c|}{$\begin{array}{l}\text { Completely } \\
\text { agree }\end{array}$} & \multicolumn{2}{|c|}{$\begin{array}{l}\text { Somewhat } \\
\text { agree }\end{array}$} & \multicolumn{2}{|c|}{$\begin{array}{c}\text { Neither agree nor } \\
\text { disagree }\end{array}$} & \multicolumn{2}{|c|}{$\begin{array}{l}\text { Somewhat } \\
\text { disagree }\end{array}$} & \multicolumn{2}{|c|}{$\begin{array}{l}\text { Completely } \\
\text { disagree }\end{array}$} & \multirow[t]{2}{*}{$\begin{array}{l}\text { Weighted } \\
\text { average }\end{array}$} \\
\hline & $n$ & $\%$ & $n$ & $\%$ & $n$ & $\%$ & $n$ & $\%$ & $n$ & $\%$ & \\
\hline I feel enthusiastic about my work. & 396 & 39.60 & 428 & 42.80 & 70 & 7.00 & 84 & 8.40 & 22 & 2.20 & 1.91 \\
\hline I feel cynical about my work. & 46 & 4.62 & 272 & 27.31 & 145 & 14.56 & 264 & 26.51 & 269 & 27.01 & 3.44 \\
\hline $\begin{array}{l}\text { I feel a low level of personal accomplish- } \\
\text { ment. }\end{array}$ & 64 & 6.40 & 232 & 23.20 & 112 & 11.20 & 269 & 26.90 & 323 & 32.30 & 3.56 \\
\hline I feel positive about my future career path. & 275 & 27.53 & 365 & 36.53 & 122 & 12.21 & 176 & 17.62 & 61 & 6.11 & 2.38 \\
\hline $\begin{array}{l}\text { I am excited about the next five years of } \\
\text { work as a music therapist. }\end{array}$ & 313 & 31.46 & 304 & 30.55 & 169 & 16.98 & 143 & 14.37 & 66 & 6.63 & 2.34 \\
\hline $\begin{array}{l}\text { My work is greeted with enthusiasm by my } \\
\text { clients/patients. }\end{array}$ & 569 & 57.36 & 352 & 35.48 & 41 & 4.13 & 24 & 2.42 & 6 & 0.60 & 1.53 \\
\hline My work is understood by my colleagues. & 171 & 17.17 & 415 & 41.67 & 137 & 13.76 & 210 & 21.08 & 63 & 6.33 & 2.58 \\
\hline My work is understood by my administrators. & 158 & 15.91 & 358 & 36.05 & 145 & 14.60 & 217 & 21.85 & 115 & 11.58 & 2.77 \\
\hline My work is valued by my patients. & 640 & 64.65 & 295 & 29.80 & 43 & 4.34 & 10 & 1.01 & 2 & 0.20 & 1.42 \\
\hline My work is valued by my colleagues. & 363 & 36.52 & 442 & 44.47 & 103 & 10.36 & 73 & 7.34 & 13 & 1.31 & 1.92 \\
\hline My work is valued by my administrators. & 268 & 27.07 & 374 & 37.78 & 152 & 15.35 & 138 & 13.94 & 58 & 5.86 & 2.34 \\
\hline $\begin{array}{l}\text { My work duties are appropriate for my quali- } \\
\text { fications. }\end{array}$ & 456 & 45.74 & 363 & 36.41 & 67 & 6.72 & 91 & 9.13 & 20 & 2.01 & 1.85 \\
\hline I can save for my retirement. & 221 & 22.21 & 222 & 22.31 & 98 & 9.85 & 176 & 17.69 & 278 & 27.94 & 3.07 \\
\hline $\begin{array}{l}\text { I have access to adequate medical insurance } \\
\text { through my work. }\end{array}$ & 360 & 36.25 & 200 & 20.14 & 88 & 8.86 & 62 & 6.24 & 283 & 28.50 & 2.71 \\
\hline $\begin{array}{l}\text { My workplace provides me with opportuni- } \\
\text { ties for advancement. }\end{array}$ & 121 & 12.21 & 192 & 19.37 & 193 & 19.48 & 213 & 21.49 & 272 & 27.45 & 3.33 \\
\hline $\begin{array}{l}\text { My workplace supports the furthering of my } \\
\text { career. }\end{array}$ & 208 & 20.99 & 257 & 25.93 & 194 & 19.58 & 162 & 16.35 & 170 & 17.15 & 2.83 \\
\hline
\end{tabular}

The final series of questions associated with burnout focused on the job conditions and work life of music therapists. When asked to respond to the question "my work duties are appropriate for my qualifications," $82.15 \%$ somewhat or completely agreed, while $11.14 \%$ somewhat or completely disagreed. Additionally, $44.52 \%$ of respondents somewhat or completely agreed with the statement "I can save for my retirement," whereas a slightly higher number, $45.63 \%$ somewhat or completely disagreed. Further, $56.39 \%$ somewhat or completely agreed with the statement "I have adequate medical insurance through my work," while $34.74 \%$ somewhat or completely disagreed. Finally, when asked two questions about career advancement, $31.38 \%$ of respondents somewhat or completely agreed with the statement "my workplace provides me with opportunities for advancement," and $46.92 \%$ of respondents somewhat or completely agreed with the statement "my workplace supports the furthering of my career."

\section{Happiness}

Table 11 provides a summary of participant responses regarding their happiness. A total of $74.12 \%$ of respondents somewhat or completely agreed with the statement "I am happy at work," $83.08 \%$ of respondents somewhat or completely agreed with the statement "I am happy I became a music therapist," and 70.45\% somewhat or completely agreed with the statement "Given the choice, I would choose music therapy as my profession again." In contrast, $16.04 \%$ somewhat or completely disagreed with the 
Table 11

Happiness

\begin{tabular}{|l|l|l|l|l|l|l|l|l|l|l|l|}
\hline \multicolumn{1}{|c|}{ Measure } & \multicolumn{2}{|c|}{$\begin{array}{c}\text { Completely } \\
\text { agree }\end{array}$} & $\begin{array}{c}\text { Somewhat } \\
\text { agree }\end{array}$ & $\begin{array}{c}\text { Neither agree } \\
\text { nor disagree }\end{array}$ & $\begin{array}{c}\text { Somewhat } \\
\text { disagree }\end{array}$ & $\begin{array}{c}\text { Completely } \\
\text { disagree }\end{array}$ & $\begin{array}{c}\text { Weighted } \\
\text { average }\end{array}$ \\
\hline & $n$ & $\%$ & $n$ & $\%$ & $n$ & $\%$ & $n$ & $\%$ & $n$ & $\%$ \\
\hline I am happy at work. & 299 & 29.99 & 440 & 44.13 & 98 & 9.83 & 113 & 11.31 & 47 & 4.71 & 2.17 \\
\hline I am happy outside work. & 425 & 42.63 & 438 & 43.93 & 64 & 6.42 & 59 & 5.92 & 11 & 1.10 & 1.79 \\
\hline I am happy I became a music therapist. & 571 & 57.50 & 254 & 25.58 & 79 & 7.96 & 74 & 7.45 & 15 & 1.51 & 1.70 \\
\hline $\begin{array}{l}\text { Given the choice, I would choose music thera- } \\
\text { py as my profession again. }\end{array}$ & 506 & 50.85 & 204 & 20.50 & 101 & 10.15 & 126 & 12.66 & 58 & 5.83 & 2.02 \\
\hline I am planning on leaving the field. & 50 & 5.04 & 112 & 11.29 & 176 & 17.74 & 196 & 19.76 & 458 & 46.17 & 3.91 \\
\hline I believe I have a future in the profession. & 407 & 40.90 & 313 & 31.46 & 158 & 15.88 & 92 & 9.25 & 25 & 2.51 & 2.01 \\
\hline
\end{tabular}

statement "I am happy at work," $8.96 \%$ somewhat or completely disagreed with the statement "I am happy I became a music therapist," and 18.49\% somewhat or completely disagreed with the statement "Given the choice, I would choose music therapy as my profession again."

When asked questions about where the field was headed and their own future in the field, $53.71 \%$ of respondents somewhat or completely agreed with the statement "I am happy with where the profession is headed," and $72.36 \%$ somewhat or completely agreed that they have a future in the field. In contrast, $21.79 \%$ of respondents somewhat or completely disagreed with the statement "I am happy with where the profession is headed," and $11.76 \%$ somewhat or completely disagreed that they have a future in the field. Finally, when asked whether they were planning on leaving the field, $16.33 \%$ somewhat or completely agreed, whereas $65.93 \%$ somewhat or completely disagreed.

\section{Total Scores by Setting}

Composite scores for work satisfaction (comprising workplace satisfaction, job satisfaction, and professional development), stress, burnout, and happiness were then calculated separately for each workplace to examine potential differences in average scores by setting. Music therapists working in medical settings reported the highest average work satisfaction score $(M=48.11)$, significantly different from all other settings (lower scores indicate higher satisfaction). In contrast, music therapists working in older adult/long term care communities reported the lowest job satisfaction ( $M=$ 63.82), followed closely by mental health settings, including addictions treatment sites $(M=62.99)$. Music therapists working in older adult/long term care communities scored significantly lower scores than music therapists working in medical settings $(p$ $<0.0001)$, children's facilities $(M=58.51, p<0.0001)$, and hospice $(M=58.21, p$ $=0.04)$. Music therapists working in mental health settings scored significantly lower scores than music therapists working in medical settings $(p<0.0001)$, children's facilities $(p=0.03)$, hospice $(p=0.04)$, and "other" workplaces (a composite of settings not included in the nine major categories; $M=58.78, p=0.04$ ).

When stress scores were examined by workplace, music therapists working in mental health settings $(M=35.9)$ and older adult/long term care communities $(M=$ 35.81) reported scores that indicated significantly higher stress than music therapists in other workplace settings; however, they were not significantly different from each other. Music therapists working in private practice/self-employed contexts ( $M=$ 41.32), hospice $(M=41.19)$, and as community music therapists $(M=41.02)$ reported the lowest stress levels.

When burnout scores were examined by workplace, music therapists working in older adult/long term care communities reported the highest levels of burnout ( $M=$ 
41.71; higher scores indicate higher burnout). This score was significantly higher than those in every other workplace except mental health settings $(M=39.88)$ and "other" workplaces $(M=39.63)$, who reported the second and third highest average scores for burnout. University/college educators reported the lowest levels of burnout $(M=$ $32.66)$, followed by music therapists in hospice $(M=35.63)$ and medical settings ( $M$ = 35.64).

When happiness scores were examined by workplace, university/college educators reported the highest levels of happiness $(M=12.67$; lower scores indicate higher happiness), followed by hospice $(M=13.52)$, medical settings $(M=13.7)$, and private practice/self-employed contexts $(M=13.8)$. University/college educators reported significantly higher happiness scores than did those working in community music therapy $(M=15.16, p=0.04)$, older adult/long term care communities $(M=15.87$, $p=0.003)$, mental health settings $(M=15.26, p=0.009)$, and "other" workplaces $(M=14.95, p=0.02)$. Music therapists working in older adult/long term care communities reported the lowest happiness, followed by music therapists working in mental health settings.

\section{Discussion}

When taken as a whole, participant responses suggest that the majority of music therapists are generally happy at work, happy with their work conditions, and satisfied with their jobs. The majority reported that they had an adequate budget to carry out their duties, an appropriate workspace, and appropriate access to instruments and that they were satisfied with the ratio of individual and group work in their workplace. Mixed responses to a series of questions regarding professional development opportunities suggest an uneven experience of professional growth opportunities, with just over half of respondents indicating they have the same learning opportunities as their colleagues in other professions do. Participant responses regarding stress and burnout were more evenly distributed across the questions, suggesting a broad range of experiences. About one third of respondents felt, to some extent, a lack of professional fulfillment, cynicism, and a low level of personal accomplishment. Conversely, approximately three quarters of respondents felt positive about their future career path, and two thirds of respondents felt excited about their next five years of work as a music therapist. Each of these components, including salary data, are discussed in detail in the following sections.

\section{Salary Data}

The average full-time salary of a music therapist was $\$ 51,099.69(S D=\$ 19,594.66)$, while the average reported salary was $\$ 44,373.64(S D=\$ 24,728.22)$. Significantly, high standard deviations indicate a wide range of salaries, suggesting disparate income levels that may impact these music therapists' perceived value in the workplace and their capacity to attain financial independence. While $57.8 \%$ of respondents somewhat or completely agreed with the statement "my music therapy income meets my basic needs," 33.7\% somewhat or completely disagreed, adding additional insight into the financial utility of these music therapists and the extent to which they are satisfied with their salaries.

Salary data for professionals in their first year of employment add to these concerns. The average reported salary for a music therapist with less than one year of experience was $\$ 34,161.60(S D=15,388.13)$, increasing marginally to $\$ 38,310.49(S D=$ $14,527.77)$ for those with two to five years of experience. It was only after working six or more years that salaries markedly increased ( $>\$ 45,193.38$ ), although salary ranges remained wide. Low entry-level salaries may be burdensome for newly credentialed professionals, who seek professional and personal independence as they enter the workforce while simultaneously grappling with student debt and salaries that do not compare favorably with their peers in the health professions (Ferrer, 2017). 
Salary data by degree and setting add further dimensionality to these averages. Respondents with a bachelor's degree reported an average salary of $\$ 39,909.85$, increasing $15.1 \%$ to $\$ 45,946.07$ for music therapists with a master's degree and another $75.4 \%$ to $\$ 80,579.51$ for music therapists with a doctorate. These data suggest that further education meaningfully increases salaries and may add support to policymakers in favor of moving to master's level entry.

Finally, the setting a music therapist works in also impacts their salary. Music therapists working in medical settings $(\$ 54,311.81)$ and in universities and colleges $(\$ 55,139.15)$ had the highest average reported salaries, whereas music therapists who identified as community music therapists $(\$ 31,808.64)$ and self-employed/private practice music therapists $(\$ 35,128.58)$ had the lowest. Interestingly, while music therapists who identified as self-employed/private practice music therapists had below average reported salaries, those working full-time in these settings reported an average salary of $\$ 47,250.29$. However, only $32 \%$ of music therapists who reported working as self-employed/private practice music therapists reported full-time salaries.

When taken as a whole, these data provide a mixed picture of the profession. According to the U.S. Bureau of Labor Statistics ${ }^{2}$ (2020, December 30a), the average full-time salary of a music therapist is on par with that of a recreational therapist (mean annual salary of $\$ 51,130.00$ ), mental health counselor (mean annual salary of $\$ 46,050.00$ ), and social worker (mean annual salary of $\$ 61,750.00$ ), but significantly lower than a speech-language pathologist (mean annual salary of $\$ 82,000.00$ ), occupational therapist (mean annual salary of $\$ 86,210.00$ ), or psychologist (mean annual salary of $\$ 87,450.00$ ). Further, given the lower salary averages for newly credentialed and early-career professionals, efforts to increase salaries appear to be important to therapists' financial independence and the stability of the profession, especially for music therapists with five or fewer years of experience.

\section{Workplace Satisfaction}

Workplace satisfaction data provide information about the conditions under which music therapists work. These data suggest that music therapists are, on the whole, satisfied with their working conditions, with $79.15 \%$ somewhat or completely agreeing with the statement "I am generally happy with my work conditions," with only $14.87 \%$ somewhat or completely disagreeing. Additionally, approximately two thirds of respondents reported an adequate budget to carry out their duties, adequate space and equipment for music therapy sessions, and the ability to carry out sessions without interruptions. Lower levels of agreement were evident in responses to some questions regarding specific budget allocations, with $49 \%$ of respondents somewhat or completely agreeing with the statement "I have a budget that allows me to incorporate technologies and equipment to practice advanced skills appropriate for my population," whereas $34 \%$ somewhat or completely disagreed with this statement. This suggests that while the majority of music therapists report adequate budget support, this support may not cover all components of their clinical work, specifically those related to technology and related equipment, impeding their ability to practice advanced skills that address client needs.

\section{Job Satisfaction}

Two categories of job satisfaction data were collected, addressing both the direct experience of work and opportunities for professional development. In general, music therapists were satisfied with their jobs, but had mixed experiences of support for professional development. More than two thirds of respondents reported satisfaction with various components of their jobs, including the ratio of group to individual sessions, the number of clients in groups, and being able to use the most appropriate music therapy interventions to meet client needs. Approximately three quarters of music therapists reported being able to access client records in a timely manner, and more than four fifths had opportunities to document client progress. Interestingly, while nearly 
two thirds of respondents indicated that their documentation of client sessions was valued by their employer, one fifth of respondents indicated that it was not valued, suggesting variations in the perceived value of clinical documentation.

Similarly, while two thirds of respondents reported inclusion in team meetings appropriate to their work duties and that their perspectives on clients were valued by team members, approximately $20 \%$ of respondents reported that they were not included in team meetings, and nearly $15 \%$ reported that their perspective was not valued when they were included. While these two response levels are relatively low overall, they do warrant further attention regarding the reasons these music therapists were excluded from team meetings and their perspectives of not being valued by their team. Advocacy efforts, including efforts to improve interprofessional communication in academic programs, may be particularly valuable in addressing these music therapists' professional experiences.

Finally, responses regarding supervision warrant further consideration. Only $37 \%$ of respondents reported some level of access to music therapy or creative arts therapy supervision, and only $56 \%$ of respondents reported access to non-music therapy supervision. This appears to suggest that music therapists need greater access to clinical supervision in their workplaces, as this access is likely to improve the quality of care provided by these clinicians and to support their professional growth. Lack of access to supervision may, in contrast, inhibit professional growth, impede the development of clinical decision-making skills, and hinder identity development (Kennelly et al., 2016; Odell-Miller \& Richards, 2009).

\section{Stress and Burnout}

Responses to a series of questions regarding workplace stress suggest that about one third of music therapists felt like a "cog in the wheel," felt "a lack of professional fulfillment," and were "not able to provide clients with the quality of care they need." In contrast, when asked a series of questions related to burnout, $80 \%$ of respondents felt enthusiastic about their work, and approximately two thirds reported feeling positive about their next five years of work as a music therapist and about their career path in general. This may suggest that while some music therapists are experiencing workplace stress, fewer music therapists are experiencing stress in ways that contribute to burnout.

When these scores are examined by setting, however, a clearer picture emerges, echoing findings reported by Gooding (2019). Music therapists working in mental health and older adult/long term care communities reported the highest levels of stress, and music therapists working in older adult/long term care communities also reported the highest levels of burnout. In tandem, music therapists working in both these settings reported the lowest levels of workplace and job satisfaction, suggesting systemic problems for music therapists in both these workplaces. In contrast, music therapists working in medical settings reported the highest levels of job satisfaction, moderate stress, and low burnout, suggesting a much more positive overall work experience. Carefully examining the workplace experiences of music therapists in each of these settings may further understanding of the factors that enhance or inhibit healthy professional experiences for music therapists and may improve professional advocacy efforts in ways that are tailored to specific settings.

Finally, a series of questions that address music therapists' perceptions of the value of their work to their clients, colleagues, and administrators adds dimensionality to advocacy work and may further reinforce the need for interprofessional education during academic training. When asked two questions about their clients' enthusiasm for and the value associated with music therapy, $93 \%$ of respondents somewhat or completely agreed with the statement "my work is greeted with enthusiasm by my clients/ patients," and 94\% somewhat or completely agreed with the statement "my work is valued by my patients." These levels of agreement decreased for colleagues (59\% and $81 \%)$ and were lower again for administrators ( $52 \%$ and $65 \%$ ), with nearly $20 \%$ of re- 
spondents somewhat or completely disagreeing with the statement "my work is valued by my administrators." These data suggest high levels of enthusiasm and value associated with music therapy by clients, generally high levels of value associated with music therapy by colleagues, and mixed levels of enthusiasm and value associated with administrators. Providing additional educational opportunities for music therapists to improve their ability to communicate the benefits of music therapy to professionals who do not have direct experiences of clinical work, along with written materials (including electronic resources), may help to improve administrators' understanding of, and associated value for, music therapy. Further, research publications that address the questions and concerns administrators have about music therapy (e.g., economic value) may further enhance this understanding.

\section{Happiness}

In general, music therapists are happy. $74 \%$ of respondents somewhat or completely agreed with the statement "I am happy at work," $83 \%$ somewhat or completely agreed with the statement "I am happy I became a music therapist," and $72 \%$ somewhat or completely agreed with the statement "I believe I have a future in the profession." In contrast, approximately $16 \%$ of respondents somewhat or completely agreed with the statement "I am planning on leaving the field," while just over half (54\%) of respondents somewhat or completely agreed with the statement "I am happy with where the profession is headed." Factors contributing to music therapists leaving the field, along with mixed perceptions regarding the direction of the field, are worthy of further investigation.

\section{Integrating Survey Findings}

These survey findings suggest a generally positive picture of music therapists practicing in the United States. At least two thirds of music therapists indicated positive responses to questions regarding their workplace and job conditions, and more than three quarters expressed some level of happiness working as a music therapist. Respondents also reported moderate levels of stress and generally low levels of burnout, with response levels similar to those reported in other health professions (Coplan et al., 2018).

In terms of future considerations for the profession, three areas stand out for further consideration, mirroring recommendations previously made by Ferrer (2017). The first and perhaps most pressing concern revealed by these survey data was the disparate salaries paid to music therapists. While the average full-time salary of a music therapist aligns with health professionals such as recreational therapist and mental health counselors, salaries varied widely, with entry-level salaries and those reported by community music therapists, self-employed/private practice music therapists, and music therapists working in older adult/long term care communities being of particular concern. Further, it appears to take, on average, up to six years for a music therapist to earn a salary above $\$ 40,000.00$, creating what may be a challenging economic environment for newly credentialed professionals. Finally, when asked to respond to the question "I can save for my retirement," only 56\% of respondents somewhat or completely agreed, whereas $46 \%$ somewhat or completely disagreed, suggesting that a number of music therapists may not feel that they can envision a future in which they are able to retire comfortably after completing their working lives as music therapists.

Second, workplace and job satisfaction vary by setting. Of particular concern are the workplace experiences of music therapists in mental health and older adult/long term care communities, who expressed the lowest levels of workplace and job satisfaction and the highest levels of stress and burnout. A closer investigation of the work experiences of music therapists in both these settings, including systemic efforts to support music therapists in these workplaces, appears to be important for professional wellbeing, especially when one considers that aged care is growing significantly in the United States (Bureau of Labor Statistics, 2020b). 
Third, increased advocacy, focused on professional development, and administrator understanding of music therapy may benefit the profession as a whole. Only $56 \%$ of respondents somewhat or completely agreed with the statement "I have the same number of learning opportunities in my job that my colleagues do," with $29 \%$ somewhat or completely disagreeing. Similarly, when asked whether their workplace provides opportunities for advancement, only $32 \%$ of respondents somewhat or completely agreed, whereas $49 \%$ somewhat or completely disagreed. A more positive outlook was provided by participant responses to the statement "my workplace supports the furthering of my career," with $47 \%$ somewhat or completely agreeing and $34 \%$ somewhat or completely disagreeing. These responses appear to suggest that music therapists have varied opportunities for professional growth and advancement, and the factors that contribute to, and impede, career development are worthy of further investigation as they may be central to enhancing the longevity and overall health of the profession.

\section{Limitations}

This study has several limitations worth noting. First, while the overall sample size allowed us to generalize the findings to the population of music therapists in the United States as whole, the sample of mid and late career music therapists (those music therapists with more than 20 years of experience) was comparatively smaller than the sample of early career music therapists (those music therapists with less than 10 years of experience). We therefore welcome further research with a focus on mid and late career music therapists. Second, because of the scope of our research, we had to make compromises in the content of some constructs in order to reduce participant burden. For example, we incorporated questions on stress and burnout from Coplan et al. (2018), which have been utilized in physician assistant and physical therapy research, but are not validated measures of stress and burnout. We therefore recommend consideration of validated measures of stress and burnout in future workforce studies. Finally, collecting salary data was far more challenging than anticipated because of the different ways music therapists are paid in the United States. We have tried to address this by providing a comprehensive picture of salary data (Tables 1-4), but additional research is needed to more clearly understand the various ways music therapists are paid and how best to record this data for research purposes.

\section{Conclusion}

The work lives of music therapists in the United States have been examined, with a focus on their workplace and job satisfaction, stress, burnout, and happiness. Survey responses suggest that the majority of music therapists are generally happy at work, happy with their work conditions, and satisfied with their jobs. However, levels of satisfaction, stress, burnout, and happiness varied by setting, suggesting a range of work experiences. Sustaining and enhancing the health of the workforce may involve one or more of the following considerations: 1) Increasing supervision opportunities for music therapists outside of their workplace, especially those that are offered on a regular basis and at low cost. Such opportunities may be especially valuable for early-career professionals. 2) Improving interprofessional communication in ways that support the integration of music therapists into interdisciplinary teams. This may include an increased focus on interdisciplinary practice in academic programs and increased support at the regional and national levels from AMTA in ways that communicate the value of music therapy to health professions colleagues. 3) Improving administrator understanding of music therapy. Targeted advocacy efforts that improve administrators' understandings of the role and value of music therapy in the workforce may improve music therapists' overall work experience, including their perceived value, associated budget support, and integration into interdisciplinary teams. Concomitantly, this may also improve workplace infrastructures that support career development. Finally, when taken as a whole, these findings also suggest that music therapists are resilient, engaged, and generally maintain a positive outlook about their future. 


\section{Acknowledgements}

The authors would like to thank Cassie Byers, MMT, MT-BC and Gene Behrens, PhD, MT-BC for their support with data analysis, including initial discussions of the data. The authors would also like to thank Dr Alejandra Ferrer, MT-BC and Allison Terrell, MMT, MT-BC for their helpful feedback on earlier versions of this manuscript.

\section{About the Authors}

Anthony Meadows, PhD, MT-BC, is the Director of Music Therapy at Shenandoah University, Winchester, VA. Correspondence: ameadows2@su.edu

Lillian Eyre, PhD, MT-BC, is Associate Professor of Music Therapy, NTT, at Temple University, Philadelphia, PA.

Audra Gollenberg, PhD, is Professor of Public Health at Shenandoah University, Winchester, VA.

\section{Appendix}

The appendices are available at the following links: Appendix A: https://voices.no/ index.php/voices/article/view/3366/3382. Appendix B: https://voices.no/index.php/ voices/article/view/3366/3383.

\section{Notes}

1. Average reported salary data includes full-time, part-time, and contractual salary data. It does not include hourly salary data, data from retired music therapists, or data from music therapists not employed as a music therapist.

2. The Bureau of Labor Statistics does not report salary data for music therapy or art therapy. Art therapists are subsumed under 29-1129 "Therapists, All Other," and music therapists appear to be subsumed under the recreational therapist category.

\section{References}

American Music Therapy Association (2018). 2018 AMTA member survey \& workforce analysis. AMTA.

Bureau of Labor Statistics, U.S. Department of Labor. (2020, December 30a). Occupational employment and wages, May 2019.https://www.bls.gov/oes/current/oes291125.htm

Bureau of Labor Statistics, U.S. Department of Labor. (2020, December 30b). Employment projections: Employment by major industry sector. https://www.bls.gov/emp/tables/ employment-by-major-industry-sector.htm

Centers for Disease Control and Prevention (CDC) (n.d.). Preferred terms for select population groups and communities. Retrieved October 7th, 2019 from https://www.cdc.gov/ healthcommunication/Preferred_Terms.html

Chang, K. (2014). An opportunity for positive change and growth: Music therapists' experiences of burnout. Canadian Journal of Music Therapy, 20(2), 64-85.

Chowdhury, M. (n.d.) Happiness at work: 10 tips for being happy at work. Retrieved January 15, 2022 from https://positivepsychology.com/happiness-at-work/

Clements-Cortes, A. (2013). Burnout in music therapists: Work, individual, and social factors. Music Therapy Perspectives, 31(2), 166-174. https://doi-org.suproxy.su.edu/10.1093/mtp/ 31.2.166

Coplan, B., McCall, T., Smith, N., Gellert, V., \& Essary, A. (2018). Burnout, job satisfaction, and stress levels of PAs. Journal of the American Academy of Physician Assistants, 31(9), 42-46. https://doi.org/10.31478/201812b

Eyre, L., \& Lee, J.-H. (2015). Mixed-methods survey of professional perspectives of music therapy practice in mental health. Music Therapy Perspectives, 33(2), 162-181. https://doiorg.suproxy.su.edu/10.1093/mtp/miv034 
Ferrer, A. (2017). Current trends and future directions in music therapy. In O. Yinger (Ed.), Music therapy: Research and evidence-based practice (pp. 125-138). Elsevier.

Gaddy, S., Gallardo, R., McCluskey, S., Moore, L., Peuser, A., Rotert, R., Stypulkoski, C., \& LaGasse, B. (2020). COVID-19 and music therapists' employment, service delivery, perceived stress, and hope: A descriptive study. Music Therapy Perspectives, 38(2), 157-166.

Gooding, L. F. (2019). Burnout among music therapists: An integrative review. Nordic Journal of Music Therapy, 28(5), 426-440. https://doi-org.suproxy.su.edu/10.1080/ 08098131.2019.1621364

Gooding, L. F. (2018a). Occupational health and well-being: Hazards, treatment options, and prevention strategies for music therapists. Music Therapy Perspectives, 36(2), 207-214. https://doi-org.suproxy.su.edu/10.1093/mtp/miw028

Gooding, L. F. (2018b). Work-life factors and job satisfaction among music therapy educators: A national survey. Music Therapy Perspectives, 36(1), 97-107. https://doiorg.suproxy.su.edu/10.1093/mtp/mix015

Kennelly, J. D., Daveson, B. A., \& Baker, F. A. (2016). Effects of professional music therapy supervision on clinical outcomes and therapist competency: A systematic review involving narrative synthesis. Nordic Journal of Music Therapy, 25(2), 185-208. https://doi.org/ 10.1080/08098131.2015.1010563

Kim, Y. (2016). Music therapists' job demands, job autonomy, social support, and their relationship with burnout and turnover intention. The Arts in Psychotherapy, 51, 17-23. https://doi-org.suproxy.su.edu/10.1016/j.aip.2016.08.001

Kim, Y. (2012). Music therapists' job satisfaction, collective self-esteem, and burnout. The Arts in Psychotherapy, 39(1), 66-71. https://doi-org.suproxy.su.edu/10.1016/j.aip.2011.10.002

Kim, Y., Jeong, J., \& Ko, M.-H. (2013). A qualitative study of Korean music therapist's turnover experiences. Arts in Psychotherapy, 40(5), 449-457. https://doi-org.suproxy.su.edu/ 10.1016/j.aip.2013.09.006

Mayo Clinic (2022). Job burnout: How to spot it and take action? Retrieved January 13, 2021. https://www.mayoclinic.org/healthy-lifestyle/adult-health/in-depth/burnout/art-20046642

mba SKOOL (2021). Job satisfaction meaning, importance, factors \& example. Retrieved January 9th, 2021 from https://www.mbaskool.com/business-concepts/human-resourceshr-terms/4394-job-satisfaction.html

Moore, C., \& Wilhelm, L. A. (2019). A survey of music therapy students' perceived stress and self-care practices. Journal of Music Therapy, 56(2), 174-201. https://doi-

org.suproxy.su.edu/10.1093/jmt/thz003

National Institute for Occupational Safety and Health (NIOSH) (2014). Stress at work. DHHS (NIOSH) Publication No. 99-101. https://www.cdc.gov/niosh/docs/99-101/ default.html\#What\%20Is\%20Job\%20Stress?

Odell-Miller, H., \& Richards, E. (2009). Supervision of music therapy: A theoretical and practical handbook (H. Odell-Miller \& E. Richards, Eds.). Routledge/Taylor \& Francis Group.

Oh, S. (2016). The effect of music therapists' burn-out and self-resilience on occupational identity. Nordic Journal of Music Therapy, 25, 142-143. https://doi-org.suproxy.su.edu/ 10.1080/08098131.2016.1180186

Trondalen, G. (2016). Self-care in music therapy: The art of balancing. In J. Edwards (Ed.), The Oxford Handbook of Music Therapy (pp. 936-956). Oxford University Press.

van Saane, N., Sluiter, J., Verbeek J., \& Frings-Dresen, M. (2003). Reliability and validity of instruments measuring job satisfaction: A systematic review. Occupational Medicine, 53(3), 191-200. https://doi.org/10.1093/occmed/kqg038

Vega, V. P. (2010). Personality, burnout, and longevity among professional music therapists. Journal of Music Therapy, 47(2), 155-179. 